\title{
Does mode matter? Measuring the effects of different types of online political engagement on offline participation ${ }^{1}$
}

\section{0 modo importa? Medindo os efeitos de diferentes tipos de envolvimento político on-line na participação off-line}

\author{
Marta Cantijoch Cunill ${ }^{2}$ \\ David Cutts ${ }^{3}$ \\ Rachel Gibson ${ }^{4}$
}

\begin{abstract}
Recent studies have shown that online participation is a multi-dimensional phenomenon that replicates and extends existing forms of political engagement. What is less clear is the mobilizing potential of these different types of activity and particularly whether they trigger offline participation. This paper addresses these questions in an analysis of citizens online and offline behaviour in the context of a UK General Election. Specifically we identify three different modes of online engagement in the campaign, profile the individuals most likely to engage in them, and examine whether they affected individuals' likelihood of voting. Our findings show that while newer social media based 'e-expressive' activities are most likely to appeal to those individuals who are not already engaged in politics they do not necessarily increase the likelihood of voting. By contrast higher consumption of news and information online during an election does appear to significantly boost individuals' chances of turning out to vote.
\end{abstract}

1 The dataset used for this project was funded by the UK Economic and Social Research Council (ESRC) through Research Grant RES-051-27-0299 and is archived at the UK Data Archive http://reshare.ukdataservice.ac.uk/850856/

2 Universidade de Manchester. Manchester, Reino Unido. https://orcid.org/0000-0001-7760-7378 E-mail: marta.cantijoch@manchester.ac.uk

3 University of Birmingham. Birmingham, Reino Unido. https://orcid.org/0000-0002-3921-7405 E-mail: d.cutts@bham.ac.uk

4 University of Manchester. Manchester, Reino Unido. https://orcid.org/0000-0002-4573-613X E-mail: rachel.gibson@manchester.ac.uk 
Keywords: online participation; digital media; voting, mobilisation; election campaign.

Resumo: Estudos recentes têm mostrado que a participação on-line é um fenômeno multidimensional que replica e amplia formas existentes de engajamento político. O que é menos claro é o potencial de mobilização desses diferentes tipos de atividade e, particularmente, se eles acionam a participação off-line. Este artigo aborda essas questões em uma análise do comportamento on-line e off-line dos cidadãos no contexto de uma eleição geral no Reino Unido. Especificamente, identificamos três modos diferentes de envolvimento on-line na campanha, relacionamos os indivíduos com maior probabilidade de participar deles e examinamos se afetavam a probabilidade de voto dos indivíduos. Nossas descobertas mostram que, embora as mais recentes atividades e-expressive baseadas em mídia social tenham maior probabilidade de atrair as pessoas que ainda não estão envolvidas na política, elas não aumentam necessariamente a probabilidade de votar. Por outro lado, o maior consumo de notícias e informações on-line durante uma eleição parece aumentar significativamente as chances de os indivíduos votarem.

Palavras-chave: participação on-line; mídia digital; votação, mobilização; campanha eleitoral. 


\section{Introduction}

Over the past two decades a growing body of work has attempted to assess the impact of the internet on citizen participation in representative politics. This research has focused primarily on voting behaviour and particularly turnout as well as more targeted forms of non-electoral engagement such as contacting, donating and petition signing (BIMBER, 1999; 2001; BEST; KRUEGER, 2005; JOHNSON; KAYE, 2003; MOSSBERGER et al., 2008; NORRIS; XENOS; MOY, 2007). While the results have generally become more positive over time the consensus has been that any mobilizing effects are small and contingent on the type of activity involved (BOULIANNE, 2009; BIMBER; COPELAND, 2013; BOULIANNE, 2015). Recent scholarship has sought to investigate more closely the idea that distinct modes of online political engagement exist and what implications they hold for citizen mobilization.

The findings to date on the first question have been consistent and positive in confirming that 'e-participation' is a multi-dimensional phenomenon which encompasses conventional activities such as campaigning and contacting government as well as more passive types of engagement such as looking for news and information (GIBSON; CANTIJOCH, 2013; HIRZALLA; VAN ZOONEN, 2011; SAGLIE; VABO, 2007). This growing understanding of the structural complexity of online participation follows in part from the expansion of items available to measure relevant activities but is also a product of 'time' itself, and particularly the recent technological diversification that has occurred with the arrival of social media platforms. One of the most interesting developments in this research has been identification of a potentially new mode of political behaviour - 'e-expressive' - that revolves around sharing and posting of political opinions (one's own or others') online. This newer mode along with lower intensity activities such as information seeking have been identified as possible triggers to more active types of both online and offline participation (HAMILTON; TOLBERT, 2012; 
BOULIANNE, 2011, 2015; GIL DE ZUNIGA et al., 2012; ROJAS; PUIG-I-ABRIL, 2009).

With regard to the second question - the mobilizing effects of different types of online activities and particularly e-expressive forms - the findings have been less clear and compelling. One reason for this is that the analyses have been conducted in contexts with limited generalizability. Specifically this has included the newly democratizing nation of Colombia and a self-selected sample of U.S. blog readers (ROJAS; PUIG-I-ABRIL, 2009; GIL DE ZUNIGA et al., 2010). In addition the indicators used to measure this mode of engagement have varied considerably with some authors focusing specifically on social media based activities while others have adopted a broader definition that encompasses more conventional web 1.0 types of expression such as signing e-petitions and emailing a politician. Given the findings from a recent literature review by Boulianne (2015) showing that social media use has minimal connection with engagement in formal modes of electoral participation, then it is clear that this methodological diversity is consequential for understanding mobilizing effects.

The main goal of this paper is to provide more robust and generalizable test of the mobilizing effects of the various modes of online political activity than has been conducted to date, focusing particularly on the impact of this new type of e-expressive engagement on more formal modes of political engagement. To do so we re-analyze the dataset used by Gibson and Cantijoch (2013) to examine online political participation in the context of the UK 2010 General Election. In this study the authors tested and confirmed a multi-factor model of e-participation that specified several distinct modes of political engagement, some of which largely replicated offline modes - e-targeted, e-campaign and e-news, while others - e-expressive - appeared to be more original to the online medium. The analysis stopped short, however, of investigating the mobilizing implications of this differentiation in terms of whether this meant different people were attracted to each mode and whether this had any consequence for their actual participation in the election. 
Our study seeks to address these questions. We do so by extending the measurement model of e-participation advanced by Gibson and Cantijoch (2013) into a full explanatory model. We do so by first identifying the socio-political correlates of those most likely to engage in each of the three modes of activity to see how far they are attracting less mobilized citizens into the electoral process. We then also compare the impact of engaging in each mode on individuals' involvement in the offline political arena and particularly the likelihood that an individual voted. In doing so we advance research on e-expressive participation by providing a clearer social media specific empirical definition of the concept. We also provide a more robust test of its mobilizing effects by examining the activities of a random sample of voters during a major nation election in an established democracy, the United Kingdom.

The research is important because it develops our understanding of the multi-dimensional nature of online participation, and in particular helps to better conceptually and empirically define this new mode of e-expressive engagement and thereby to evaluate its mobilizing potential. In addition, we provide a new case for analysis which ceteris paribus is helpful in extending the generalizability of the findings produced to date. Moreover the case of the UK is arguably more representative of the global experience of online participation than either of the two countries that have featured in the research to date into e-expressive participation. As an established democracy with relatively stable levels of voter turnout and a large majority of citizens online, the UK arguably presents a more standardized test of the impact of digital technologies on citizen behaviour than the less institutionalized environment of Colombia where internet use is much less widespread, and constitutes more of a novelty. Moving to the other end of the spectrum, although the U.S has been responsible for the lion's share of research into online participation its consistently low levels of voter turnout, combined with very high levels of use of online media during elections, actually make it something of an anomaly in comparative research on internet effects (VACCARI, 
2013). ${ }^{5}$ By presenting a new single-case study this paper contributes to the debate about the robustness of previous findings and informs future researchers wishing to adopt a comparative perspective.

\section{Research on Online Participation}

The study of the internet and political participation at the individual level has expanded rapidly since the late 1990s. Early work by Bimber and others demonstrated significant but small effects on engagement in the formal political arena (BIMBER 1999, 2001; SHAH et al., 2001; JOHNSON; KAYE, 2003). Other more critical studies reported that the internet was largely reinforcing existing participatory biases in conventional politics and possibly even reducing the pool of active citizens (HILL; HUGHES, 1998; KRAUT et al., 1998; DAVIS, 1999; NIE, 2001; BONFADELLI, 2002; NORRIS, 2001; AND 2002; WILHELM, 2000). A third strand of research supports the notion that the digital media environment shouldn't be understood as an individual-level factor of change but as a transformation of the context where action takes place (BIMBER, 2017).

As measures of online political activities expanded more nuanced models of citizens 'uses and gratifications' (BLUMLER; KATZ, 1974) in using the internet were developed and applied to questions of mobilization. This greater differentiation of internet use led to increasingly positive findings emerging with information seeking in particular being regarded as a trigger to engagement in more active types of online and offline participation (HARDY; SCHEUFELE, 2005; MOY et al., 2005; XENOS; MOY, 2007; MOSSBERGER et al., 2008; QUINTELIER; VISSERS, 2008; BAKKER; DE VREESE, 2011; GIL DE ZUNIGA et al., 2012). As Boulianne's (2009) meta-analysis of a decade's worth of study of the topic has pointed out, however, despite the positive

5 Vaccari compares the US population on use of the internet to find political news with publics in five established European democracies and Australia in elections from 2006-2010 and concludes that 'American citizens show a much greater inclination than voters in any other country to engage with the campaign online.' (Figure 9.1: 133). 
trajectory in findings, the real impact on levels of public participation has been largely negligible.

Following Boulianne's review article increased attention has been given to improving the measurement and modelling of e-participation. The continued expansion of survey items to measure new forms of web 2.0 or social media based political activities such as blogging, tweeting and sharing information through social network sites have fuelled these efforts, with scholars adopting increasingly sophisticated techniques to identify different types of e-participation (SAGLIE; VABO, 2009; BAKKER; DE VREESE, 2011; LEUNG, 2009; GIBSON; CANTIJOCH, 2013). While the precise modes of online participation identified to date have varied based on data availability, the results have consistently shown a division of activities into more active and passive types that largely mirror those found in offline participation. Gibson and Cantijoch (2013) have provided one of the most comprehensive analyses in this regard. Using a particularly rich data source from the UK 2010 General election that contained multiple indicators of online electoral and non-electoral activities, they identified four main modes of activity that included attention to political news, more targeted actions such as contacting a politician and donating to a political cause, party and campaign involvement, and finally a newer cluster of expressive actions revolving posting and sharing political views through social media.

Investigation of the mobilizing effects of these various forms of online engagement has been relatively limited to date and produced mixed findings. The evidence is strongest in support of online news and information seeking as a significant stimulus to political engagement (BOULIANNE, 2009). Subsequent panel data analysis has confirmed this very convincingly by showing how attention to election news increased levels of political interest (BOULIANNE, 2011) and turnout (HAMILTON; TOLBERT, 2013). For e-expressive activities the findings are somewhat less clear cut. The general consensus is that these actions serve as a stimulus to more active modes of online participation, however, there is some question over whether these effects carry over 
to offline participation (ROJAS; PUIG-I-ABRIL, 2009; GIL DE ZUNIGA et al., 2010). In addition the study of effects has been divided in its measurement and understanding of the core concept. Gil de Zuniga et al. (2010) use a three point scale that arguably captures less relevant web 1.0 based political activities such as emailing a newspaper editor or a politician, and signing an e-petition. Rojas and Puig-i-Abril (2009), however, apply more sophisticated modelling techniques to create a latent construct that relies exclusively on newer social media specific actions such as posting political commentary to a blog or social networking site. Interestingly, Gil de Zuniga et al. (2010) go on to examine the socio-political correlates of the e-expressive mode, and find that those engaging in it are typically already political engaged and fit a more conventional participant profile. Rojas and Puig-i-Abril (2009) do not report the correlates of those engaging in their version of e-expressive participation. Finally the samples used in both analyses are also problematic in that one relies on blog users recruited through open online invitations, thereby creating problems of generalizability to the broader population (GIL DE ZUNIGA, 2010). The other draws on survey responses from Colombia's urban population which as noted above, and as the authors themselves confess, limits the generalizability of their conclusions to the wider group of democratized nations.

Drawing together the literature on online participation to date therefore it is clear that e-participation, like its offline counterpart, is a complex phenomenon that can and should be divided into sub-modes of activity. Furthermore it appears that less intensive modes such as news gathering provide a stimulus to increased levels of political engagement. What is not so clear is whether other and potentially newer types of e-participation, and particularly these newer social media oriented activities act in a similar manner. This paper seeks to investigate this question and does so in three main stages. First we specify and test three main modes of online political engagement that draw on the main measurement models and findings established in the extant literature. Then we examine the individual characteristics of those engaging in them and 
query the extent they are attracting the usual participatory suspects. Finally we compare the effect each type has subsequent offline political activity and specifically whether an individual voted or not.

\section{Data and Methods}

As noted above to conduct the research we re-analyzed the 2010 survey data analysed by Gibson and Cantijoch (2013). ${ }^{6}$ This dataset is particularly useful for examining questions about the structure of online participation since it contains an unusually rich set of items measuring a wide range of individuals' political opinions and online activities during an election period. It was conducted as a post-election face-to-face survey by BMRB, a UK polling company ${ }^{7}$ and measured a total of nine election related online activities, four non-electoral online actions and their direct offline counterparts well as political attitudes and standard demographics. Given our primary interest was in the relationship between different modes of online activity and electoral mobilization we concentrated on the nine election relevant items. This included whether one paid attention to a range of official and unofficial news and information, undertook a number of more formal actions to support parties and candidates, as well as the more expressive activities such as posting, forwarding or embedding political content in your own or others social media profile. The specific items used and their frequencies are presented in Table 1. The overall $\mathrm{N}$ was 1,960, of which there was a sub-sample of 1,379 internet users ${ }^{8}$.

6 Available from the UK Data Service at http://ukdataservice.ac.uk/, reference number SN 850856.

7 The fieldwork was conducted between 20 and 26 May 2010. Control of quotas affecting likelihood of being at home (age and working status within sex) was applied following a one stage ACORN and region stratification. The data was weighted to ensure that demographic profiles matched those for all adults in Great Britain aged eighteen or over.

8 A proportion of the sample did not have access to the internet which meant they could not engage in online activities. Given that the focus of the paper is to assess how individuals engaged with the online campaign during the 2010 general election, it was decided to omit these respondents from the subsequent analyses. 
Table 1: Online Campaign Activities of UK Voters in the 2010 General Election (weighted data)

\begin{tabular}{llll}
\hline Type Of Activity & Total Sample (\%) & Internet users (\%) & $\mathrm{N}$ \\
\hline Official Campaign & & & \\
\hline Read/accessed official sites & 15.5 & 20.6 & 301 \\
$\begin{array}{l}\text { Signed up as supporter/for e-news } \\
\text { Used online tools to campaign / }\end{array}$ & 4.6 & 6.1 & 89 \\
promote parties & 3.3 & 4.3 & 63 \\
Total official campaign engagement & 18.6 & 24.8 & 363 \\
\hline Non-Official Campaign & & & 539 \\
\hline Read/accessed mainstream news sites & 27.6 & 36.7 & 112 \\
$\begin{array}{l}\text { Viewed/accessed non-official online } \\
\text { video }\end{array}$ & 5.7 & 7.6 & 62 \\
$\begin{array}{l}\text { Joined/started political group on a } \\
\text { SNS }\end{array}$ & 3.2 & 4.2 & 88 \\
$\begin{array}{l}\text { Posted political comments to own/ } \\
\text { other blog/SNS }\end{array}$ & 4.5 & 6.0 & 50 \\
$\begin{array}{l}\text { Forwarded non-official content (jokes, } \\
\text { news items) }\end{array}$ & 2.6 & 3.4 & 21 \\
$\begin{array}{l}\text { Embedded/reposted non-official } \\
\text { content }\end{array}$ & 1.1 & 1.4 & 613 \\
$\begin{array}{l}\text { Total non-official campaign } \\
\text { engagement }\end{array}$ & 31.4 & 41.7 & 651 \\
\hline \begin{tabular}{l} 
Overall Activity \\
\hline
\end{tabular} & 33.4 & 44.4 & \\
\hline
\end{tabular}

Source: BMRB National Face to Face Quota Survey of 1,960 UK adults May 20 $0^{\text {th }}-26^{\text {th }} 2010$.

Official Campaign Question: Please could you tell me, whether you have done any of the following activities in relation to official parties or candidates online?

Non-official Campaign Question: Which, if any, of the following activities did you do online during the election campaign over the last month?

As a first step we replicated the measurement model of Gibson and Cantijoch (2013) and used the nine election-relevant items to define three modes or factors of political engagement. Thus the three items measuring news and information gathering activities i.e. visiting official campaign sites, YouTube and the mainstream media were used to define an E-news mode. The three items that captured the informal sharing, forwarding or posting of political content and opinion through social 
media or email we labelled E-expressive ${ }^{9}$. Finally a third E-party mode was specified that focused on more active and collective efforts to get involved in the campaign itself either through using party provided online tools, registering for official e-news updates, and joining or starting an SNS/Facebook politically-related group during the election. ${ }^{10}$ The three latent e-participation variables specified correspond to those presented in Table 2.

Table 2: Expected Dimensions of E-campaign participation using items from BMRB UK 2010 Survey

\begin{tabular}{ll}
\hline Factors & Variables \\
\hline \multirow{3}{*}{ E-Party } & Used online tools to campaign /promote parties \\
& Joined/started political group on a SNS \\
& Signed up as supporter/for e-news \\
& Embedded/reposted non-official content \\
E-Expressive & Forwarded non-official content (jokes, news items) \\
& Posted political comments to own/other blog/SNS \\
& Read/accessed official sites \\
E-news & Read/accessed mainstream news sites \\
& Viewed/accessed non-official online video \\
\hline
\end{tabular}

The measurement model was tested through simultaneous confirmatory factor analysis to establish how far the three factor model provided an accurate representation of the underlying patterns of participation within the population of interest.

Having specified our measurement model we then extended it into a full structural equation model that simultaneously then estimates the correlates of each mode of engagement and their impact on voting, controlling for a range of alternative plausible explanatory factors. In terms

9 The items in question do not specify the political content that is exchanged or posted although it does provide examples such as posting comment on blogs or a Facebook wall or forwarding video, news stories and jokes. This definition thus emphasizes the public 'speech' aspect rather than a wider range of more creative, artistic type of non-verbal content which could constitute e-expressive participation.

10 Involvement in a Facebook group we recognize may not have been linked with a political party, however, on balance we considered that it constituted a more organized, higher intensity and 'formal' type of engagement with the campaign than the actions associated with the other two modes. 
of the correlates of each mode we included the range of conventional predictors such as levels of individual civic and economic resources, as well cognitive and attitudinal factors such as interest in politics, political trust, and a partisan identification (PARRY et al., 1992; VERBA et al., 1995; DALTON, 2002; PATTIE et al., 2004; WHITELEY; SEYD, 1996; ZMERLI et al., 2007). Given the very limited empirical evidence available to date on who is engaging in each mode we do not formulate specific hypotheses about the impact of these variables on the likelihood of undertaking each type of activity. Instead we opt for a more conservative strategy of testing the null hypothesis that the characteristics predicting involvement in electorally relevant and more conventional modes of offline participation will also be significant for predicting online engagement. While we apply this 'default' position to all three modes we expect it to hold most strongly for the 'e-party' mode given the higher levels of partisanship and political involvement likely to be present among those undertaking these activities. The one major deviation from the norm or null hypothesis that we specify is in relation to age. Although political activity typically increases with age, the long standing skew in internet usage toward younger people and particularly now in regard to social media (RAINIE et al., 2012) we argue is likely to moderate or even invert this relationship. We expect this to be particularly so for the 'e-expressive' mode given its reliance on social media tools.

Having profiled the individuals' most likely to engage in each mode of behaviour we then examine their impact on offline participation and particularly whether an individual voted or not in the 2010 general election, controlling for relevant socio-economic and other political characteristics. Here we use the profiles generated in step two of our analysis to develop more specific predictions about the relative likelihood of each mode leading to a significant increase in the likelihood of voting.

\section{Model and Results}

To conduct our analysis we used structural equation modelling which allowed us to simultaneously examine and estimate all three components 
of our analysis. ${ }^{11}$ Figure 1 shows a path diagram of the full model. Below we outline the components of the model corresponding to each step of the analysis and present the results.

Figure 1: Path diagram of the full structural equation model tested.

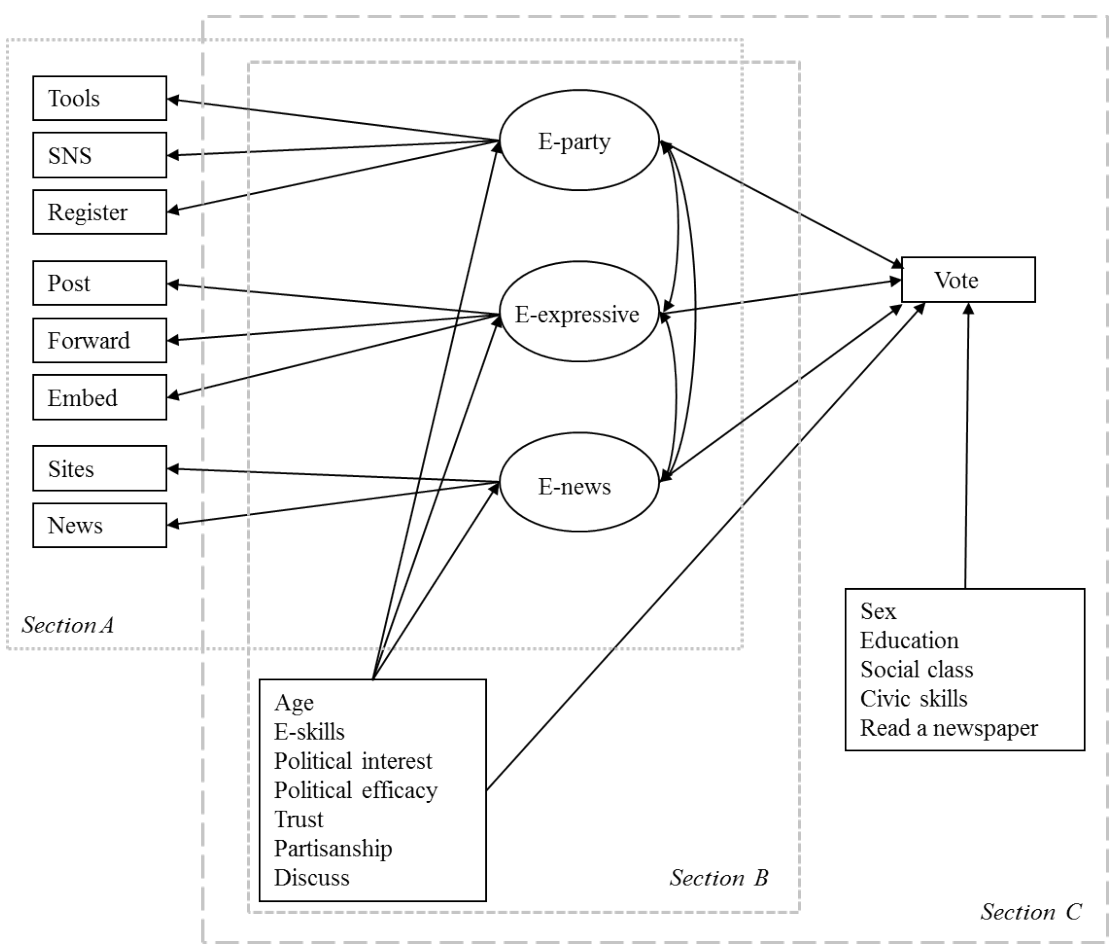

11 The model was fitted using Mplus 6 software (Muthén and Muthén, 2005). The analysis of the small amount of missing data (less than 4.2 per cent of sample size) was handled through the estimation-mobilisation (EM) algorithm to compute missing data estimates using full information maximum likelihood (FIML) (Muthén and Muthén, 2005). This estimation approach is preferred because it provides unbiased parameter estimates and standard errors under missing at random (MAR) (Little and Rubin, 1987). We use the WLSMV estimator because it handles missing data on the covariates which is where our missing data was situated - please see Asparouhov and Muthen (2010) for the discussion of missing data using Weighted Least Squares modelling which is available on the Mplus website at www.statmodel.com/. All the regression models reported in this article are probit models. 


\section{Developing a typology of e-participation: the measurement model}

In a first step we specified our three factor model of online participation shown in Table 2 and estimated it using latent variable modelling ${ }^{12}$. This is represented in our Figure 1 as Section A. Overall we find support for the three factors and confirmation of the results produced by Gibson and Cantijoch (2013). One deviation was noted in the loading of the online video item on the E-news factor which failed to reach significance and it was removed from the analysis. While this would seem to contradict the findings of Gibson and Cantijoch (2013) it is clear from initial analyses using the more simple measurement section of the model (i.e. Section A) that the item loaded with the other indicators. However, when the factor was entered into the full structural model presented here to test the mobilization questions (i.e. sections B and $\mathrm{C}$ ) problems emerged with the online video item ${ }^{13}$. Table 3 provides the standardised and unstandardized regression estimates of measurement indicators on the three e-participation latent variables (the results are drawn from full model in Figure 1).

12 In simple terms, the latent variable model can be written:

where

$$
\mathrm{Y}_{\mathrm{ij}}=\lambda_{\mathrm{ij}} \eta_{\mathrm{j}}+\varepsilon_{\mathrm{ij}}
$$

$$
\eta_{\mathrm{j}}=\gamma_{\mathrm{ij}} \mathrm{X}_{\mathrm{ij}}+\zeta_{\mathrm{j}} \text {. }
$$

$Y_{i j}$ is the $i$-th indicator of the $\mathrm{j}$-th latent variable $\eta_{i}$, with loading $\lambda_{\mathrm{ij}}$ and unique factors $\varepsilon_{\mathrm{ij}}$ (i.e. unshared variance and error). The latent variables $\eta_{i}$ accounts for the effects of the regressions $\gamma_{i j}$ on the exogenous causes $\mathrm{X}_{\mathrm{iij}}$, as well as the variance $\zeta_{\mathrm{i}}$ not accounted for by $\mathrm{X}_{\mathrm{ii}}$. Here it is assumed that error terms $\left(\varepsilon_{\mathrm{ij}}\right.$ and $\left.\zeta_{\mathrm{j}}\right)$ have a mean of zero (Cutts et al, 2011). In addition to the model shown in equations (1) and (2) and Figure l, the latent variables $\eta_{j}$ were allowed to correlate freely, representing the non-independence of e-campaign participation. The model structure also allowed all exogenous predictors to covary freely.

13 The e-video variable failed to contribute very much to the E-news latent variable (as measured by the STYX and variance explained). Indeed, it produced less than $45 \%$ of the variance in e-video. This variable also has a highly skewed distribution which meant that its inclusion as a covariate in the final model of voter turnout was highly problematic despite our attempts to deal with this using standard techniques. For instance, during testing, its inclusion resulted in model instability as indicated by poor model fit statistics. Subsequent exploratory testing revealed some modest but nevertheless problematic correlation with a number of items on the other latent factors. Due to these numerous problems and in the interest of obtaining the most parsimonious model, we decided to omit this variable from the analysis. 
Table 3. Estimates of E-Campaign indicators on latent variables (factor loadings, full model)

\begin{tabular}{|c|c|c|c|c|}
\hline Variables & Estimates $(\boldsymbol{\beta})$ & $\mathrm{SE}$ & StdYX & $\mathbf{R}^{2}$ \\
\hline $\begin{array}{l}\text { E-Party } \\
\text { Used online tools to campaign / } \\
\text { promote parties }\end{array}$ & 1.00 & - & 0.85 & 0.73 \\
\hline $\begin{array}{l}\text { Joined/started political group on } \\
\text { a SNS }\end{array}$ & 0.91 & 0.10 & 0.79 & 0.62 \\
\hline Signed up as supporter/for e-news & 0.99 & 0.08 & 0.85 & 0.72 \\
\hline \multicolumn{5}{|l|}{ E-Expressive } \\
\hline $\begin{array}{l}\text { Embedded/reposted non-official } \\
\text { content }\end{array}$ & 1.00 & - & 0.96 & 0.93 \\
\hline $\begin{array}{l}\text { Forwarded non-official content } \\
\text { (jokes, news items) }\end{array}$ & 0.84 & 0.08 & 0.85 & 0.72 \\
\hline $\begin{array}{l}\text { Posted political comments to own/ } \\
\text { other blog/SNS }\end{array}$ & 0.86 & 0.08 & 0.86 & 0.73 \\
\hline \multicolumn{5}{|l|}{ E-news } \\
\hline Read/accessed official sites & 1.00 & - & 0.94 & 0.89 \\
\hline $\begin{array}{l}\text { Read/accessed mainstream news } \\
\text { sites }\end{array}$ & 0.68 & 0.07 & 0.70 & 0.49 \\
\hline
\end{tabular}

Note: Data is weighted. Correlations between e-party and e-expressive $\left(0.55^{* *}\right.$ standardised); e-party and e-news (0.38** standardised); e-expressive and e-news (0.36** standardised).

The standardised estimates (StdYX) are equivalent to factor loadings from a common factor analysis. The unstandardized estimates for online tools (e-party) embedded/reposted campaign content (e-expressive) and official candidate sites (e-news) are constrained to equal 1 with estimates for the other indicator variables providing relative values. All indicators are significantly and positively correlated with each latent variable. The coefficients and the large standardised loadings for each indicator suggest that each latent variable is a good representation of the variables. This is confirmed by the r-squared statistics which indicate the proportion of variance in each indicator which is explained by the model. Given that the indicators are regressed only on the latent variables, the r-squared values are the square of the standardised coefficients. The e-party latent variable reproduces more than two thirds of the variance 
in online tools and official register and just under for unofficial SNS. For e-expressive, it reproduces nine tenths of the variance in embedded/ reposted campaign content and more than two-thirds of the variance in forwarded campaign content and posted comments. Finally, the e-news latent variable reproduces nine tenths of the variance in official websites but less than half in mainstream news websites. To test the significance of the independent contribution of each indicator we re-specified the model without each of the indicators in turn and found that the inclusion of each indicator made a significant contribution in the reduction of $\log$ likelihood.

\section{Who engages in e-participation?}

Having confirmed the multi-modal nature of online engagement in the 2010 UK General Election we move on to the more original component of our analysis and the questions of how far each type can be seen as leading to voter mobilization. To do this we first find out who is engaging in the different e-campaign modes. This involves extending our measurement model, where the latent variables are considered to be the cause of the relationships from a set of indicator variables (e.g. online tools, visiting sites, sharing online information), into a multiple indicator, multiple cause or MIMIC model (JÖRESKOG; GOLDBERGER, 1975) where the latent variables are being caused by other, exogenous, variables (e.g. political interest, internal political efficacy, partisanship etc) (ZUMBO, 2005; FIELDHOUSE; CUTTS, 2010; CUTTS et al., 2011). In figure 1 Section $B$ this is shown by the causal arrows running into the latent variable and represents the regression of the latent variables on the covariates.

As shown in figure 1 section $\mathrm{B}$, we measure age effects as a categorical variable with separate dummies for young people aged 18-29, middle aged 30-44, middle older aged $45-59$ and old age 60 plus. We also include an internet skills variable ${ }^{14}$ to measure the overall competence

14 E-skills is also a count variable 0-4. The z-score for skewness and kurtosis was 5.65 and -7.56 . Hence it was $\log$ transformed to deal with non-normality. 
of internet use, as developed by new media scholars to test for any independent effects on rates of participation, offline and online (BEST; KRUEGER, 2005). ${ }^{15}$ Individuals who have an interest in politics, feelings of internal efficacy, trust British politicians, discuss politics with friends and family and are partisans are more likely to become politically active. ${ }^{16}$ The estimates for these models are presented in table 4 .

Table 4. Regression of latent variables on covariates by E-Campaign: E-Party, E-Informal and E-Communication in the 2010 General Election (Full Model)

\begin{tabular}{|c|c|c|c|c|c|c|}
\hline \multirow{2}{*}{$\begin{array}{l}\text { Variables } \\
\text { Young Age 18-29 }\end{array}$} & \multicolumn{2}{|c|}{$\begin{array}{l}\text { E-Party Estimates } \\
(\beta)(\text { StdYX) }\end{array}$} & \multicolumn{2}{|c|}{$\begin{array}{l}\text { E-Expressive Esti- } \\
\text { mates }(\beta)(\text { StdYX })\end{array}$} & \multicolumn{2}{|c|}{$\begin{array}{l}\text { E-news Estimates } \\
(\beta)(\operatorname{Std} Y X)\end{array}$} \\
\hline & $0.57^{* * *}$ & .26 & 0.59 *** & .23 & $0.73^{* * *}$ & .28 \\
\hline Middle Age 30-44 & 0.13 & .06 & 0.53 * & .22 & $0.64 * *$ & .27 \\
\hline $\begin{array}{l}\text { Middle/Older Age } \\
45-59\end{array}$ & 0.04 & .02 & 0.07 & .03 & 0.04 & .01 \\
\hline $\begin{array}{l}\text { Lots of Political } \\
\text { Interest }\end{array}$ & $0.51^{* * *}$ & .19 & 0.25 & .08 & $0.41^{* * * *}$ & .13 \\
\hline Political Efficacy & 0.01 & .03 & 0.04 & .10 & $0.04^{* * *}$ & .09 \\
\hline Trust & $0.72^{* * *}$ & .23 & 0.18 & .05 & 0.79 米然 & .22 \\
\hline E-Skills & $0.68 * *$ & .17 & $1.77^{\text {米䧇 }}$ & .36 & $1.41^{* * * * 2}$ & .29 \\
\hline No Partisanship & $-0.36^{*}$ & -.17 & -0.16 & -.05 & -0.01 & -.00 \\
\hline $\begin{array}{l}\text { Discuss politics } \\
\text { with friends }\end{array}$ & 0.13 & .07 & $0.51^{\text {\%* }}$ & .22 & $0.36^{\text {***; }}$ & .16 \\
\hline $\mathrm{R} 2$ & .25 & & .31 & & .33 & \\
\hline
\end{tabular}

Data is weighted. $\mathrm{N}=1379$. "* Significance at the 0.01 level. * Significance at the 0.05 level. Reference category for Age $=$ Age 60 plus.

15 This variable correlated highly with other indicators of socio-economic status (SES) such as education, social class and civic skills. In order to improve the parsimony of the model and to reduce the risk of multicollinearity, the variable internet skills was chosen as the only predictor included in this section of the model to measure SES effects. This selection was based on the relevance that this concept is acquiring in the study of online engagement and on its performance in the model.

16 Political interest is coded as a dummy - lots of political interest $=1$; all others $=0$. Feelings of efficacy is distributed normally with no evidence of skewness. However, missing data here (for 17 cases) was recalculated by using the mean score. Efficacy was included as a continuous variable. Trust in politicians was found to be moderately positively skewed $(z$-score $=2.6)$ and there was also evidence of negative kurtosis. We log transformed this variable to remove non-normality and included it as a continuous variable. Partisanship is coded as a dummy - no partisanship $=1$; partisanship $=0$. Discussing politics with friends and family (over the past 12 months) is codes also as a dummy - has discussed $=1$; hasn't discussed $=0$. 
For each model we can see that the variance explained (r-square) is at least one quarter of the total. The results for our individual predictors are interesting in that to a significant extent they challenge the null hypothesis that the same factors that are relevant for electorally relevant types of offline participation are also linked with online modes. Certainly the findings with regard to age are particularly striking with those aged between 18-29 being the most likely to engage in all forms of e-participation (e-party, e-expressive and e-news). Furthermore online skills appear to be one of the most important drivers to engaging in these modes of participation, even when accounting for a range of traditional predictors of political engagement. Somewhat contrary to our expectations, however, the lure of e-expressive is less strong among younger voters than e-news and particularly e-party. While the standardized coefficients for age show that e-news and e-expressive also appeal to slightly older voters, e-party is actually much more clearly dominated by the youngest cohort. Thus, despite the fact that those engaging in e-party activities are significantly more likely to be interested in politics and to be partisans there is a reversal of expectations regarding age which does signal that online channels may allow parties to reach a new pool of previously untapped activists. ${ }^{17}$

Perhaps the clearest evidence in favour of the mobilization thesis, however, comes from our findings about who is engaging in e-expressive activities. Essentially these are a group of young tech-savvy individuals who are quite keen to talk about politics but who are not particularly involved or engaged with the political process as measured through their levels of partisanship, trust in politicians, interest in politics or feelings of efficacy.

17 Further evidence to suggest e-party activism is offering a new channel for less new types of volunteers to get involved and help parties and candidates is provided by the finding that e-expressive and e-party factors were correlated quite strongly at 0.55 . This suggests some support for the idea presented earlier that party related activities occurring online may be taking on a more expressive and self-directed quality that differs from the formal and party controlled character they followed in the pre-internet and particularly social media era. 


\section{E-campaign participation on vote in 2010}

Given the results of our profiling exercise have shown that there are distinctive features of those engaging in the three modes of online engagement which indicate varying levels of proximity to the already engaged or 'ideal' citizen type, in a final step we formalize these findings into a series hypotheses that specify the effect of each mode on offline participation and in particular, voting in the 2010 general election, controlling for socio-economic and other political factors.

Overall we argue that the most likely predictor of the three will be greater engagement in e-news seeking. As noted in our review of the literature this mode of online activity has been consistently and increasingly convincingly linked with increases in participatory attitudes as well as more intensive offline and online political behaviours. In addition, based on the profiling results reported above we know that those seeking information are not highly partisan although they are likely to be at least somewhat interested in politics. As such they may be more undecided over whether to vote and whom to vote for, and thus open to persuasion by the information and mobilization efforts of others they experience online.

By contrast, increased engagement in e-party activities is not anticipated to significantly increase the likelihood of an individual voting. As we have seen, despite its youth appeal and the potentially new source of volunteers it might help supply, e-party activists are highly engaged in the election and it is unlikely that more engagement of this type would increase their commitment to turnout. Finally for e-expressive activities we have competing expectations. On the one hand we might expect the e-expressive factor to prompt greater offline participation. Its more social and informal nature may provide an easier point of entry for people who are typically less engaged and interested in politics compared to other modes. Conversely, precisely because this type of activity is informal, even if it is campaign related, and revolves around the sharing of unofficial content and expression of personal opinions through peer networks, one can argue that it would be unlikely to connect people 
with more formal and active channels of engagement such as voting. Certainly this lack of connection has been endorsed by a number of studies to date (BOULIANNE, 2015). Thus while we do not expect its effect to reduce turnout we might expect it to be neutral or have no effect. We capture the above reasoning in the following three hypotheses.

H1: Levels of e-news news consumption during the election campaign will be positively and significantly related to an individiual's likelihood of voting.

H2: Levels of e-party activities and/or e-expressive activities during the election campaign will not be significantly related to an individual's likelihood of voting.

H3 Levels of e-expressive activities during the election campaign will be positively and significantly related to an individual's likelihood of voting.

To test these hypotheses the MIMIC model is extended to a full structural equation model where the latent and observed variables are included simultaneously and the direct effects of both are estimated on the vote in the 2010 UK general election (JÖRESKOG, 1973; BOLLEN, 1989). This extension of the model is represented in Section C of Figure 1. The model includes socio-demographic factors (sex, social class and education ${ }^{18}$ ) and civic skills ${ }^{19}$, variables that have been identified in the wider participation literature as strongly linked to individuals' propensity to participate (PARRY et al., 1992; VERBA et al., 1995). Whether an individual reads a daily newspaper is included as a dummy variable to control for the effects of the mainstream offline news media on voting. ${ }^{20}$

The model also allows us to decompose the direct and indirect effects of various factors affecting voting in 2010. For instance, age, e-skills,

18 Sex is a categorical variable. Both class and education are continuous variables.

19 Civic skills is a count variable 0-4. However, closer inspection of the data found that it was positively skewed with a z-score of 12.12 for skewness and a large amount of kurtosis. The Kolmogorov-Smirnov Z test of normality also revealed that the distribution was non-normal. Therefore we log transformed the civic skills to deal with the moderate to excessive amount of skewness.

20 Reading a newspaper is coded as a dummy - reads a newspaper $=1$; doesn't read a newspaper $=0$. It is also important to note that we ran our analysis with separate dummies for tabloids and broadsheet newspapers but their inclusion made little or no difference to the model findings. 
political interest, political efficacy, trust in politicians, partisanship and discussing politics with friends are allowed to condition both on the three latent variables measuring e-campaign participation and vote in 2010. Thus these variables have an effect via these measures of e-campaign participation as well as directly. So for example, part of the effect of political interest is transmitted via the e-campaign participation latent variables. However, the effect of e-campaign participation on voting in 2010 is net of the direct effect of political interest etc. and can be considered as an e-participation effect, albeit partly determined (itself) by these other variables.

The direct effect estimates for these regression models are presented in Table $5^{21}$. Before discussing this set of final findings it is important to report the fit of the full structural equation model that included Sections $\mathrm{A}, \mathrm{B}$ and $\mathrm{C}$ together, assessed against standard goodness of fit measures. Despite presenting the results in three stages it should be remembered the findings are actually simultaneously estimated and that the breakdown of the results is done simply for clarity of interpretation to address our three research questions. The statistics reveal a good overall fit of our model to the data. The Comparative Fit Index (0.949) and the Root Mean Square of Approximation (0.024) indicate a 'good' model fit (Hu and Bentler, 1999).

Table 5. Regression of 2010 Vote on E-Campaign (E-Party, E-Expressive and E-news) and Control Variables (Full Model)

\begin{tabular}{lll}
\hline \multirow{2}{*}{ Variables } & \multicolumn{2}{l}{ Vote 2010 } \\
& \multicolumn{2}{l}{ Estimates $(\beta)($ StdYX $)$} \\
\hline Sex & -0.10 & -.04 \\
Young Age 18-29 & $-1.48^{* * *}$ & -.51 \\
Middle Age 30-44 & $-0.97^{* * *}$ & -.36 \\
Middle/Older Age 45-59 & $-0.44^{* * *}$ & -.16 \\
Read a Newspaper & 0.08 & .03 \\
\hline
\end{tabular}

21 After running a number of well established tests (including tolerance statistics and variance inflation indicators), we found no evidence of multicollinearity in the model. 
Table 5. Continutation

\begin{tabular}{lll}
\hline \multirow{2}{*}{ Variables } & \multicolumn{2}{l}{$\begin{array}{l}\text { Vote 2010 } \\
\text { Estimates }(\beta) \text { (StdYX) }\end{array}$} \\
\hline Social Class & $0.20^{* * *}$ & .19 \\
Education & $0.12^{* * *}$ & .14 \\
Lots of Political Interest & 0.19 & .05 \\
Political Efficacy & -0.02 & -.05 \\
Trust & $0.43^{* *}$ & .11 \\
Civic Skills & 0.32 & .06 \\
E-Skills & -0.34 & -.06 \\
No Partisanship & $-0.39^{* * *}$ & -.11 \\
Discuss politics with friends & 0.16 & .06 \\
E-Party & -0.07 & -.06 \\
E-Expressive & -0.01 & -.01 \\
E-news & $0.33^{* * *}$ & .30 \\
R2 & .41 & \\
CFI & .949 & \\
RMSEA & .024 & \\
\hline
\end{tabular}

Data is weighted. $\mathrm{N}=1379$. * Significance at the 0.01 level. * Significance at the 0.05 level. Reference category for Age $=$ Age 60 plus.

Table 5 shows that our final sub-model has a reasonable degree of explanatory power and explains more than forty per cent of the variance in turnout in 2010. The results also confirm the importance of the traditional predictors of vote such as class, age and education although gender and civic skills were not strong drivers. Political attitudes clearly did play a role with those more trusting of politicians being significantly more likely to vote while those less attached to a political party were significantly less likely to participate. Political interest and discussing politics with friends were surprisingly insignificant. Given that both variables were significant predictors of two of the three e-engagement variables (as shown in Table 4) however, it is likely that their effects are being absorbed by our latent variables and now exerting an indirect effect on our dependent variable. Internal political efficacy, reading a 
daily newspaper and online skills were also insignificant after controlling for other factors. ${ }^{22}$

Turning to the e-participation variables, we find support for both $\mathrm{Hl}$ and $\mathrm{H} 2$ but not $\mathrm{H} 3$. While higher engagement in e-news activities during the campaign had a significant effect on turnout, the e-party and e-expressive modes of engagement did not. As noted above, however, these insignificant effects we consider to have quite different explanations. Those who are engaging in party related activities online are already highly likely to vote and thus not gaining any additional impetus to vote. Those carrying out the more informal acts associated with the e-expressive mode such as forwarding jokes, news items to friends and family are not as positively oriented toward the political system. It appears that these activities do not bring them any closer to more institutionalized forms of politics.

Despite the lack of support for $\mathrm{H} 3$ we do not rule out a mobilising effect of e-expressive participation. It may be that it increases the propensity to engage in other types of informal offline activities such as political consumerism or even protest. It may also lead on to other types of more active online activities which in turn lead to offline participation. This latter interpretation certainly conforms with the findings from the structural modelling of Rojas and Puig-i-Abril (2009) who found no direct effects for e-expressive participation on offline participation but did detect an indirect effect through more active uses of social media to contact family and friends. Due to our reliance on cross-sectional data we were unfortunately unable to test this more sequential and causal pathway between our various modes of online engagement.

By contrast, and again as predicted, those engaging in e-news activities were significantly more likely to vote. Indeed the standardised effect

22 Here we defined internal political efficacy as whether politics was too complicated or not. Conventional theories and models of turnout often define political efficacy as an individuals sense that he/she has the skills and resources to influence the political process. This measure is commonly used in rational choice models of turnout - whether an individual feels there is a chance of being influential or not (see Riker and Ordershook, 1973; Blais, 2000) - and civic voluntarism where a combination of social characteristics, contexts and psychology are used to explain political participation. 
is extremely large, and after age, it was the most important predictor of turnout in the 2010 general election when compared against other variables. The predicted probability of voting for those individuals engaged in e-news seeking is 0.19 holding all other variables at their mean. ${ }^{23}$ In addition to higher levels of political interest we also find that those consuming e-news generally trust politicians and feel that they understand politics but do not feel close to a political party. As such we can see them as a version of 'critical citizens' (NORRIS, 1999) in that they are detached from partisan politics but not alienated from the political system as a whole and open to persuasion by the campaign and information that they access online.

\section{Conclusions}

The emergence of a new channel for engagement in politics in the form of digital media has raised new questions about the multi-dimensional nature of political participation. Does online participation differentiate or cluster into distinctive modes in the manner of offline participation? If so, are all modes created equal in terms of their mobilizing potential or are some more likely to bring new 'faces' in the political process? Finally how far does each type link into engagement in offline politics and particularly its conventional forms? Is e-participation helping to revive a commitment to the representative process? In this paper we have sought to address these questions by offering a more sophisticated measurement of e-campaign participation which has then been used to test its mobilisation effects on offline involvement, here defined as voting.

Using structural equation modelling, we first re-tested a typology that classified e-campaign behaviours into different modes taking into account two characteristics - level of active engagement required and the target of the behaviour (i.e. formal or informal). Our results supported

23 Mplus does not provide probabilities. However, it is possible to translate probit coefficients into probabilities using the formula: $\operatorname{prob}(\mathrm{y}=1)=\mathrm{f}($-threshold $+\mathrm{b} 1 * \mathrm{x} 1+\mathrm{b} 2 * \mathrm{x} 2+\mathrm{b} 3 * \mathrm{x} 3 \ldots \ldots)$, where $\mathrm{f}$ is the cumulative normal distribution function and the threshold value is taken from the final Mplus output (a negative sign is transformed into a positive sign and vice versa). The predicted probabilities were derived from the final model (Table 5). 
the differentiation of e-campaign activities into three main types: e-party, which centred on involvement with official campaign actors but in more self-organized and autonomous ways; e-expressive which involved interaction in public and unofficial forums with peers and other citizens to voice one's political views, e-news consumption of online news about the election emerged as a third distinct mode of engagement.

In a second step we identified the characteristics of those engaging in each of the three modes of e-campaign activity. Our findings supported the idea that they formed distinct modes of political activity in that those engaging in them exhibited certain socio-political differences. In particular the e-expressive type of participation appealed more to the average voter i.e. those who were less engaged and positively oriented toward the political system than was the case for our other two modes. We interpreted this as signalling that e-expressive forms of activity may provide a potentially new channel to engage a wider group of citizens in the political process and thereby hold a stronger mobilising potential than the other types of online participatory engagement available to people. The e-party and e-news modes were somewhat closer to the norm of conventional participants offline, although the younger age profile of both modes, particularly the e-party showed how new media technologies may be creating a new group of younger digital party activists.

Finally, we tested the mobilising effect of these different forms of e-campaign participation on voting in the 2010 UK general election. In line with a growing number of studies and our profiling of those engaging in e-news gathering activities we found this activity to be significantly linked to an increased likelihood of voting, confirming a mobilising potential for internet use in this regard. Engagement in the e-expressive and e-party modes, however, were found to have no effect on individuals' likelihood of voting, This finding is in line with our expectations set out in H2. Those people who undertake e-party activities are already highly political motivated and thus primed to vote. The lack of a connection between e-expressive activities and voting is different however in that we know this type of engagement attracts a broader group 
of non-traditional participants. As such while it may be mobilizing people to participate in the campaign it does not appear to then stimulate them to follow through and turnout to vote.

The results are significant both conceptually and methodologically. First, they confirm that e-participation is not a homogenous or uni-dimensional concept but should be disaggregated into coherent clusters of activity, as with offline participation. Second, while some of these types of e-participation attract already active citizens, others draw in the less politically engaged and while they are not necessarily increasing their interest in voting, they may be raising levels of political engagement and support for the system in other subtler and more diffuse ways. Finally, despite being undertaken largely by those who are highly interested and supportive of the political system, accessing news and information about the election does appear to increase individuals' likelihood of voting. Viewed in the light of other recent studies from the U.S. (BOULIANNE, 2011; HAMILTON; TOLBERT, 2012) that have reported significant effects of online campaign information on individuals interest in the election and turnout using panel data (thereby controlling for endogeneity), such findings give an important additional boost to the mobilizing effects of internet use in a new electoral context. Further work is needed to look into the positive spiral of involvement detected here between attention to online news and information and political interest. In particular it will be important to probe the democratizing implications of such trends. If online resources are increasing interest and turnout primarily among those who are already attentive to the political system, then a reinforcement of participatory biases may be the end result, thus countering, if not challenging claims for mobilisation. 


\section{References}

BAKKER, T. P.; DE VREESE, C. H. Good news for the future? Young people, internet use, and political participation. Communication Research, v. 38, n. 4, p. 451-470, 2011. BARNES, S. H.; KAASE, M. et al. Political action: mass participation in five Western democracies. Beverly Hills, California: Sage Publications, 1979.

BENNETT, W. L. Communicating global activism: strengths and vulnerabilities of networked politics. Information, Communication E Society, v. 6, n. 2, p. 143-168, 2003. BEST, S. J.; KRUEGER, B. S. Analyzing the representativeness of internet political participation. Political Behavior, v. 27, n. 2, p. 183-216, 2005.

BIMBER, B. Information and American democracy. Cambridge: Cambridge University Press, 2003.

Information and political engagement in America: the search for effects of information technology at the individual level. Political Research Quarterly, n. 54, p. 53-67, 2001.

. The internet and citizen communication with government: does the medium matter? Political Communication, v. 16, n. 4, p. 409-428, 1999.

Three prompts for collective action in the context of digital media. Political Communication, v. 34, n. 1, p. 6-20, 2017.

.; COPELAND, L. Digital media and traditional participation over time in the US. Journal of Information, Technology E Politics, v. 10, n. 2, p. 125-137, 2013.

BIMBER, B.; FLANIGAN, A.; STOHL, C. Reconceptualizing collective action in the contemporary media environment. Communication Theory, v. 15, n. 4, p. 365-388, 2005. BLAIS, A. To vote or not to vote: the merits and limits of rational choice theory. Pittsburgh: University of Pittsburgh Press, 2000.

BLUMLER, J. G.; KATZ, E. The uses of mass communications: current perspectives on gratifications research. v. 3. Beverly Hills: Sage publications, 1974.

BONFADELLI, H. The internet and knowledge gaps. A theoretical and empirical investigation. European Journal of Communication, v. 17, n. 1, p. 65-84, 2002.

BOULIANNE, S. Does internet use affect engagement? A meta-analysis of research. Political Communication, v. 26, n. 2, p. 193-211, 2009.

Social media use and participation: a meta-analysis of current research. Information, Communication \& Society, v. 18, n. 5, p. 524-538, 2015.

Stimulating or reinforcing political interest: using panel data to examine reciprocal effects between news media and political interest. Political Communication, v. 28, n. 2, p. 147-162, 2011.

CUTTS, D.; FORD, R.; GOODWIN, M. J. Anti-immigrant, politically disaffected or still racist after all? Examining the attitudinal drivers of extreme right support in Britain in the 2009 European election. European Journal of Political Research, v. 50, n. 3, p. 418-440, 2011.

DALTON, R. Citizen politics. Public opinion and political parties in advanced industrial democracies. New York: London: Chatham, 2002. 
Democratic challenges, democratic choices: the erosion of political support in advanced liberal democracies. Oxford: Oxford University Press, 2004.

DAVIS, R. The web of politics. The internet's impact on the American political system. New York: Oxford University Press, 1999.

FIELDHOUSE, E.; CUTTS, D. Does diversity damage social capital? A comparative study of neighbourhood diversity and social capital in the US and Britain. Canadian Journal of Political Science (Revue Canadienne de Science Politique), v. 43, n. 2, p. 289-318, 2010.

GIBSON, R.; CANTIJOCH, M. Conceptualizing and measuring participation in the age of the internet: is online political engagement really different to offline? Journal of Politics, v. 75, n. 3, p. 701-716, 2013.

GIL DE ZÚÑIGA, H.; JUNG, N.; VALENZUELA, S. Social media use for news and individuals' social capital, civic engagement and political participation. Journal of Computer Mediated Communication, v. 17, n. 3, p. 319-336, 2012.

GIL DE ZÚÑIGA, H.; VEENSTRA, A.; VRAGA, E.; SHAH, D. Digital democracy: reimagining pathways to political participation. Journal of Information, Technology 6 Politics, v. 7, n. 1, p. 36-51, 2010.

GUEORGUIEVA, V. Voters, MySpace and YouTube: the impact of alternative communication channels on the 2006 election cycle and beyond. Social Science Computer Review, v. 26, n. 3, p. 288-300, 2007.

HAMILTON, A.; TOLBERT, C. J. Political engagement and the internet in the 2008 US presidential elections. In: ANDUIZA, E.; JENSEN, M. J.; JORBA, L. (Eds.). Digital media and political engagement worldwide: a comparative study. Cambridge: Cambridge University Press, 2012. p. 56-79.

HARDY, B. W.; SCHEUFELE, D. A. Examining differential gains from internet use: comparing the moderating role of talk and online interactions. Joumal of Communication, v. 55, n. 1, p. 71-84, 2005.

HILL, K. A.; HUGHES, J. E. Cyberpolitics: citizen activism in the age of the internet. Lanham: Rowman \& Littlefield, 1998.

HIRZALLA, F.; VAN ZOONEN, L. Beyond the online/offline divide: convergences of online and offline civic activities among youth. Social Science Computer Review, 2010. Disponívelem: https://www.researchgate.net/publication/289378620_Beyond_the_onlineoffline_divide_Convergences_of_online_and_offline_civic_activities_among_youth. Acesso em: jun. 2018.

HU, L.; BENTLER. P. M. Cutoff criteria for fit indexes in covariance structure analysis: conventional criteria versus new alternatives. Structural Equation Modeling, v. 6, n. 1, p. 1-55, 1999.

JOHNSON, T.; KAYE, B. A boost or bust for democracy? How the web influences political attitudes and behaviours in the 1996 and 2000 presidential elections. Press/Politics, v. 8, p. 9-34, 2003. 
JÖRESKOG, K. G. A general method for estimating a linear structural equation system. In: GOLDBERGER, A. S.; DUNCAN; O. D. (Eds.). Structural Equation Models in the Social Sciences. New York: Seminar Press, 1973. p. 85-112.

JÖRESKOG, K. G.; GOLDBERGER, A. S. Estimation of a model with multiple indicators and multiple causes of a single latent variable. Journal of the American Statistical Association, v. 70, n. 351, p. 631-639, 1975.

KRAUT, R.; KIESLER, S.; MUKHOPADHYAY, T.; SCHERLIS, W.; PATTERSON, M. Social impact of the internet. What does it mean? Communications of the ACM, v. 41, n. 12, p. 21-22, 1998.

LEUNG, L. User-generated content on the internet: an examination of gratifications, civic engagement and psychological empowerment. New Media \& Society, v. 11, n. 8, p. 1.327-1.347, 2009.

LITTLE, R. J. A.; RUBIN, D. B. Statistical analysis with missing data. New York: Wiley-Interscience, 1987.

MOSSBERGER, K.; TOLBERT, C.; MCNEAL, R. Digital citizenship. The internet, society, and participation. Cambridge: The MIT Press, 2008.

MOY, P.; MANOSEVITCH, E.; STAMM, K.; DUNSMORE, K. Linking dimensions of internet use and civic engagement. Journalism and Mass Communication Quarterly, v. 82, n. 3, p. 571-586, 2005.

MUTHÉN, L. K.; MUTHÉN, B. O. Mplus user's guide. Los Angeles: Muthén \& Muthén, 2005.

NIE, N. Sociability, interpersonal relations and the Internet. American Behavioral Scientist, n. 45, p. 420-435, 2001.

NORRIS, P. (Ed.). Critical citizens: global support for democratic government. Oxford: Oxford University Press, 1999.

Democratic phoenix: reinventing political activism. Cambridge: Cambridge University Press, 2002.

Digital divide: civic engagement, information poverty, and the internet. Cambridge: Cambridge University Press, 2001.

PARRY, G.; MOYSER, G.; DAY, N. Political participation and democracy in Britain. Cambridge: Cambridge University Press, 1992.

PATTIE, C.; SEYD, P.; WHITELEY, P. Citizenship in Britain: values, participation \& democracy. Cambridge: Cambridge University Press, 2004.

QUINTELIER, E.; VISSERS, S. The effect of internet use on political participation: an analysis of survey results for 16 year olds in Belgium. Social Science Computer Review, v. 28, n. 4 , p. $411-427,2008$.

RAINIE, L.; SMITH, A.; SCHLOZMAN, K. L.; BRADY, H.; VERBA, S. Social media and political engagement. Washington: Pew Internet \& American Life Project, 2012.

RHEINGOLD, H. Smart Mos: the next social revolution. Cambridge: Basic Books, 2002.

RIKER, W. H.; ORDERSHOOK, P. C. An introduction to positive political theory. Englewood Cliffs: Prentice-Hall, 1973. 
ROJAS, H.; PUIG-I-ABRIL, E. Mobilizers mobilized: information, expression, mobilization and participation in the Digital Age. Journal of Computer-Mediated Communication, v. 14, n. 4, p. 902-927, 2009.

SAGLIE, J.; VABO, S. I. Size and e-democracy: online participation in Norwegian local politics. Scandinavian Political Studies, v. 32, n. 4, p. 382-401, 2009.

STOKER, G. Why politics matters. Basingstoke: Palgrave, 2006.

SYLVESTER, D. E.; MCGLYNN, A. J. The digital divide, political participation, and place. Social Science Computer Review, v. 28, n. 1, p. 64-74, 2010.

TEORELL, J.; TORCAL, M.; MONTERO, J. R. Political participation: mapping the terrain. In: VAN DETH, J. W.; MONTERO, J. R.; WESTHOLM, A. (Eds.). Citizenship and involvement in European democracies: a comparative analysis. London: Routledge, 2007. p. 334-357.

VACCARI, C. Digital politics in Western democracies: a comparative study. Baltimore: Johns Hopkins University Press, 2013.

VERBA, S.; NIE, N. H. Participation in America: political democracy and social equality. New York: Harper \& Row, 1972.

.; KIM, J. Participation and political equality: a seven-nation comparison. New York: Cambridge University Press, 1978.

VERBA, S.; SCHLOZMAN, K. L.; BRADY, H. E. Voice and equality: civic voluntarism in American politics. Cambridge: Harvard University Press, 1995.

WILHELM, A. G. Democracy in the Digital Age: challenges to political life in cyberspace. New York: Routledge, 2000.

WHITELY, P. F.; SEYD, P. Rationality and party activism: encompassing tests of alternative models of political participation. European Journal of Political Research, v. 29, n. 2, p. 215-234, 1996.

XENOS, M.; MOY, P. Direct and differential effects of the internet on political and civic engagement. Journal of Communication, v. 57, n. 4, p. 704-718, 2007.

ZMERLI, S.; NEWTON, K.; MONTERO, J. R. Trust in people, confidence in political institutions, and satisfaction with democracy. In: VAN DETH, J.; MONTERO, J. R.; WESTHOLM, A. (Eds.) Citizenship and involvement in European democracies: a comparative analysis. London: Routledge, 2007. p. 35-65.

ZUMBO, B. D. Structural equation modelling and test validation. Encyclopedia of statistics in behavioral science. [s. 1.], 2005. Disponível em: https:/onlinelibrary.wiley.com/ doi/pdf/10.1002/0470013192.bsa654. Acesso em: jun. 2018. 


\section{About the authors}

Marta Cantijoch is a Lecturer in Politics at the University of Manchester. Her research interests include political behaviour, political participation, elections and voting, political communication and the effects of new media. She has published a range of articles on questions about how citizens use the internet to engage in politics and develop their citizenship skills. She is co-editor of the Routledge Handbook of Elections, Voting Behaviour and Public Opinion (2017).

David Cutts is a Professor in Political Science at the University of Birmingham. His research focuses on electoral and political behaviour, party and political campaigning, political and civic engagement, party competition and methods for modelling political behaviour. He is joint lead editor of Political Studies Review and an Associate Fellow at Chatham House on the Europe Programme.

Rachel Gibson is Professor of Politics at the University of Manchester. She has published a wide range of articles and books on the question of how digital technologies are changing the way in which election campaigns are fought and won. She has also been a Principal Investigator of the Australian Election Study since 2001 and co-directed the internet component of the British Election Study (iBES) in 2015.

Date of submission: 10/01/2018

Date of acceptance: 29/06/2018 